\title{
The Accountability and Transparency Agenda: Emerging Issues in the Global Era
}

\author{
Ellen Hazelkorn
}

\section{Introduction}

Higher education is usually seen as serving the public interest because its benefits extend to the individual and society. As such, there is an implicit "social contract" that balances public support through taxation and public policy in exchange for academic and institutional autonomy. But, universities and colleges are increasingly being accused of being insufficiently accountable to students and society for learning outcomes, graduate attributes and life-sustaining skills in exchange for the funding they receive. These tensions are coming to dominate the discourse about higher education and affect our institutions around the globe. They take slightly different forms in different countries but, essentially, questions are being asked about the degree of transparency and accountability about what higher education institutions (HEI), both public and private, are doing about these matters.

This paper reviews some of the issues and tensions driving the accountability and transparency agenda and asks if our existing systems are (still) fit for the 21st century? Can traditional forms of academic accountability, such as quality assurance and accreditation, continue to deliver public assurance of the quality of institutional performance or are new/different forms required? How do we balance different perspectives with expanding societal demands? There are three sections. Part 1 situates growing concerns about accountability and transparency in the context of the massification, internationalisation and globalisation of higher education. Part 2 discusses some theoretical and policy issues, looking at Ireland as

\author{
E. Hazelkorn $(\bowtie)$ \\ Dublin Institute of Technology, Dublin, Republic of Ireland \\ e-mail: ellen.hazelkorn@dit.ie; info@bhassociates.eu \\ E. Hazelkorn \\ BH Associates, Dublin, Republic of Ireland
}

(C) The Author(s) 2018

A. Curaj et al. (eds.), European Higher Education Area: The Impact of Past and Future Policies, https://doi.org/10.1007/978-3-319-77407-7_26 
example of the overall trend. Part 3 concludes with a review of emerging questions around quality, performance and accountability in the global era. Finally, the paper previews the chapters in this section of the book.

\section{Massification, Globalisation and Internationalisation}

The United States had the first mass system of higher education, beginning in the aftermath of World War 2, but massification is now evident everywhere. Over the last fifty years, the combination of demographic growth, economic and labour market changes, globalisation and internationalisation have pushed up the demand for higher education participation, and for graduates. Everywhere, our (higher) education systems have been transformed, spurred by the recognition that education is key to driving sustainable social and economic growth, empowering personal satisfaction and success, and improving societal outcomes. Despite the lingering effects of the 2008 financial crisis and the Great Recession, across OECD countries, there is on-going evidence of increased demand for highly skilled people, with skill gaps already appearing in some EU Member States (Eurostat 2017a). This rise in the number of graduates has, however, had little impact on the graduate premium (OECD 2017, 106-111), because as Carnevale et al. (2013, 7) argue, "[e]mployers are still willing to pay more for the college degree - a symbol of a worker's attainment of the knowledge, skills, and abilities that improve productivity".

These dynamics help explain the continuing rise in gross enrolment rates, which increased from around 10\% in 1970 to over 35\% by 2015 (World Bank 2016). This trend is buttressed by an on-going upswing in students as a percentage of the world's population, forecast to rise from 4\% in 2012 to $10 \%$ by 2040 (Calderon 2012; Maslen 2012). While the "relationship between demography-or more specifically the size of the younger age cohorts - and higher education enrolment levels is a complex one", the number of tertiary students has risen from $100 \mathrm{~m}$ in 2000 to $207 \mathrm{~m}$ today and is estimated to climb to more than $262 \mathrm{~m}$ by 2025 (UNESCO 2017). Amongst EU-28 countries, there were $19.5 \mathrm{~m}$ tertiary education students in 2015, compared with $11 \mathrm{~m}$ in 1992 (Teichler and Bürger 2005), of which $7.2 \%$ were following short-cycle tertiary courses, $61.4 \%$ were studying for Bachelor's degrees, $27.8 \%$ for Master's degrees and 3.7\% for Doctoral degrees (Eurostat 2017a). It is anticipated that demographic change will see a gradual reduction in the number of domestic students, but this is likely to be offset by increases in participation rates to hitherto under-represented groups, greater numbers of international students, and life-long learning (LLL) - in other words by on-going massification. The "political will [exists] to pursue the expansion of higher education systems in most countries", and there is "still significant potential for growth in participation in many countries" (Vincent-Lancrin 2008b, 52).

Today, across OECD countries, educational attainment rates among 25-34-year-olds have reached $43 \%$ compared with only $26 \%$ in 2000 . Among EU-28 countries, $33.4 \%$ of those aged $25-54$ have attained a tertiary qualification 
(Eurostat 2017b), and the EU 2020 Strategy aims to push the proportion of 3034-year-olds to 40\% (Eurostat 2017c). As education opportunities have expanded, so has the diversity of the student cohort. Until the $1990 \mathrm{~s}$, males outnumbered female students (Vincent-Lancrin 2008a). Since then, the pattern has reversed with expectations that women will be in the majority, albeit statistics hide differences in terms of field and careers (Sursock 2015). The socio-economic composition of tertiary education is also broadening, with greater numbers of new communities of students, older students studying while learning, part-time and online students, international and transnational students, and new immigrant groups. As life expectancy improves, there will be on-going demand for continuing education and retraining opportunities.

International student mobility has been another impactful trend. The number of foreign students in tertiary education worldwide has risen from 0.8 million (late 1970 s) to 4.6 million (today) to 8 million (2025). While OECD countries continue to attract $73 \%$ of all students enrolled abroad, the international market is "dividing up quite differently with countries like Japan [and some European countries] getting a larger share", and the US is losing out proportionately (ICEF 2015; OECD 2014; Fisher 2017). Various factors affect student choice, one of the biggest of which is quality or rather "perceptions" of quality, which is where global rankings, reputation and quality intersect (Hazelkorn 2015, 88-89); this can include institutional prestige or country profile and whether the qualification will be recognized by future employers.

These developments have correspondingly led to a spectacular growth in the number and range of tertiary educational programmes and providers, with boundaries between public and private blurring. While the exact number of institutions is hard to pin down, the World Higher Education Database (WHED 2017) suggests there are 18,500 degree-awarding institutions today, ${ }^{1}$ while others report as many as 26,368 "universities" (Webometrics 2017). It is estimated that in 2009, the last year for which comprehensive data is available, $31 \%$ of students worldwide were enrolled in private (both non-profit and for-profit) higher education (PHE) (Middlehurst and Fielden 2011, 3; Hazelkorn 2016). Across the EU-27, the PHE share represents only c.12\% provision, with a modestly higher share for Europe more broadly defined (Levy 2012). A related but different phenomena are branch campuses, which have increased from 84 in 2000 to approximately 311 in 2017, catering for approximately 180,000 students (Mok et al. 2017). Whatever the actual figure, what is clear is that the total number and diversity of tertiary providers has grown dramatically over recent decades with "almost all regulatory bodies or quality assurance agencies mak[ing] little distinction [any longer] between public and private institutions" (Mohamedbhai 2017).

Globalisation and internationalisation have introduced other changes and challenges. Because higher education's talent and knowledge productive capacity and capability is co-dependent with national requirements for attracting mobile talent,

\footnotetext{
${ }^{1}$ Refers to higher education institutions offering at least a 4-year professional diploma or a post-graduate degree and which are recognized by their national competent bodies.
} 
services and products, higher education has been "drawn into the logic of capitalist expansion and world market-making" (Robertson et al. 2016). A globalised economy has certain pre-requisites and inter-dependencies around mobility flows, e.g. recognition of credentials and quality assurance; standard setting and guidelines; data infrastructure, definition and collection; credit transfer and accumulation systems; etc.

Increasing compatibility and comparability across national education systems is a prerequisite for international student mobility. Educational accreditation standards and information play an important role in removing barriers to student exchanges and supporting the global market for advanced skills. International co-operation in this field is essential (OECD 2017, 296).

Accordingly, a wide array of bilateral and international agreements, frameworks and organisations have evolved over the recent decades (Gallagher 2010; Salmi 2015). Together, a rules-based global architecture to enable, support and sustain trans-nationalising education and research is emerging in much the same way as, for example, the World Trade Organization (1995) deals with the "rules of trade between nations" in order to "help producers of goods and services, exporters, and importers conduct their business" (WTO) or the World Intellectual Property Organization (1967) "lead[s] the development of a balanced and effective international intellectual property (IP) system that enables innovation and creativity for the benefit of all" (WIPO). Trust and (re)assurance around quality is the essential lubricant.

This growing complexity of the global system has transformed higher education and reframed its relationship to the state and society in each country. Whereas historically the state provided for the needs of universities, today the university provides for the needs of society (Hazelkorn 2017, 13-14; Dill and Beerkens 2010, 4). Nation-states remain the primary arena of/for higher education, but higher education systems are open systems, with HEIs operating as global players within and across a multi-dimensional, multi-level and multi-lateral paradigm (Enders 2004). Boundaries are necessarily permeable. Indeed, the enormity of the educational enterprise has meant many practices previously taken for granted and enshrined as "principles" of academic life - such as collegiality, self-assessment, self-reporting and peer review, and self-governance-have all come under pressure and challenge. What was possible and normal for a small elite system with students of similar socio-economic and cultural backgrounds comprising c.5\% of the population is extremely challenging for more complex systems and societies anticipating rates of over $60 \%$, if not beyond. Thus, many emergent tensions and conflicts derive from and reflect the sheer logic of complex decision-making and massified systems, as well as changes in expectations around the "social contract" - the role and purpose of (higher) education in/for society and the economy. As Trow $(1974,91)$ noted, as the system expands in terms of students and providers, matters of higher education come 
to the attention of larger numbers of people, both in government and in the public... [they will] have other, often quite legitimate, ideas about where public funds should be spent, and, if given to higher education, how they should be spent.

Together with the desire to ensure "more rapid responses from institutions of higher education" to societal requirements (Neave 1998, 2012), higher education organisations and management have, by necessity, been required to acquire greater professionalization with corresponding changes in structures and leadership. There has been a parallel re-balancing of relations between higher education and the state.

Concerns about quality and standards, effectiveness and efficiency, and regulation and governance (within institutions and at the system level) - to name but a few key issues - are matters which now concern constituencies far beyond the jurisdiction of higher education. Once higher education is recognised and promoted as the "engine of the economy" (Castells 1996), then how it is governed and managed, along with matters of performance and productivity, necessarily comes to the fore. As King (2018) says, "the very centrality of higher education outcomes for national competitiveness and prosperity and the taxpayer and consumer funds that are deployed for support require that universities and colleges are subject to levels of public scrutiny." Institutions regularly engage in benchmarking while countries look for international comparability and solutions as they seek to "develop policies to enhance individuals' social and economic prospects, provide incentives for greater efficiency in schooling, and help to mobilise resources to meet rising demands" (OECD 2017, 3). Accordingly, pursuance and assessment of quality and excellence have become geopolitical matters. Which bring us to issues of transparency and accountability.

\section{The Accountability and Transparency Agenda}

Over recent decades, the concepts of accountability and transparency have taken centre stage in public and policy discourse. The Merriam-Webster Dictionary (2017) defines accountability as not simply accounting for or recording one's activities, but actually acknowledging both the obligation and the responsibility to be accountable. For Bovens (2003), contemporary concerns about accountability "has moved beyond its bookkeeping origins and has become a symbol of good governance, both in the public and in the private sector." Hence, there is an emphasis on being transparent-being responsive and answerable as well as being straightforward and truthful-for one's actions. Bovens et al. $(2014,16)$ argue that these issues are associated with the "ever increasing complexity of governance" as well as broader concerns about elites and the misuse of public funds "fuelled by scandal and perceived misuse of authority in both the private and public sectors" (Leveille 2013, 6).

Others have tied accountability to the rise of neo-liberalism and new public management (NPM) and the adoption of private corporate mechanisms to public 
sector organizations not just higher education (King 2009, 42). A key influence has been the view that the market and competitive principles are a more effective mechanism to effect change and bring about greater efficiency and benefit for customers and consumers, including students. It is operationalized in terms of control and power, often with respect to resource allocation (Morrell 2009). A strong evaluative culture has materialised, with an emphasis on measuring, assessing, comparing and benchmarking performance and productivity—using a preponderance of quantitative indicators in a variety of "governance indices" - to drive, monitor and evaluate behaviour as well as focusing on/funding outputs, outcomes and impacts rather than inputs (Neave 2012; Dahler-Larsen 2011; Erkkila and Piironen 2009).

Over the years, governments have extracted themselves from direct control, ownership and/or management of (public) services. Governance has shifted from top-down intervention - in some cases micro-management - to an indirect softer, steering from a distance (Erkkilä 2007). However, recent concerns about the limits of the market in many domains, such as banking and financial services, especially in the aftermath of the global financial crisis, have provoked concerns about insufficient oversight. In response, many governments have stepped up their role endeavouring to (re)regulate in order to ensure a closer alignment with societal and national objectives, adapting various forms of networked governance. This altered relationship between the state and its various agencies reflects a broader transformation in public attitudes towards public services and the level of tax required to support them, as well as the degree of public trust between different sectors of society (Ferlie et al. 2008) and public interest in the effective and efficient use of public resources and the contribution and value back to society. This helps explain the broader movement towards enhanced democratic governance and political accountability (Lijphart 2012).

With respect to higher education, a war-of-words has opened up in many countries around educational relevance, graduate attributes, and the contribution of research as higher education institutions are accused of being too self-serving and insufficiently interested in student learning or outcomes (Hazelkorn and Gibson 2017). These issues speak to concerns about holding higher education accountable and responsible

to the public for quality. It is about meeting the needs of students, society and government. It is about the effectiveness and performance of colleges and universities as well as their transparency of their efforts. Accountability is about higher education serving the public interest and about higher education as a public trust (Eaton 2016, 325).

Higher education has traditionally relied on peer-review and self-reporting and has asked the public to trust this form of accountability. But, this system no longer seems adequate. The absence of acceptable, appropriate or sufficient (independent or external verification) mechanisms and tools has been a source of growing public scrutiny and questioning. Rankings have emerged to fill the gap; but their methodology is unsuitable, the indicators are insufficiently meaningful, and the data 
is unreliable. Their over-emphasis on research and elite universities has also made them educationally and politically contestable.

These concerns have re-focused attention on the "social contract" between higher education and the "society of which it is a part" (Zumeta 2011, 134) and the extent to which that bargain is being upheld and interests balanced-sometimes portrayed as emergent tensions between (university) autonomy versus (societal) accountability (Scott 1998; Estermann and Nokkala 2009). The European University Association acknowledged that the current debate around "institutional autonomy" reflects the

constantly changing relations between the state and higher education institutions and the degree of control exerted by the state...in response to the demands of society and the changing understanding of public responsibility for higher education (Estermann and Nokkala 2009, 6).

A survey for the US Association of College and University Governing Boards (AGB) also acknowledged this friction, with about 57\% of members agreeing/ strongly agreeing that public perceptions of higher education had declined over the past 10 years (Gallup 2017). While people believe "some kind of postsecondary education or training" is important (Lederman 2017), surveys and studies in the United States and United Kingdom continue to highlight growing public concerns around credential relevance, career readiness and cost versus price (Public Agenda 2016; HEFCE 2010; Immerwahr and Johnson 2010; Lumina 2013; Ipsos MORI 2010). European students have said they favour independent reports on the quality of universities and programmes to help them decide where to study (Eurobarometer 2009, 5). Ideological as well as deepening cultural divides, evidenced by recent elections in the US, UK, France and other countries, have fed a narrative about the higher education's isolation from the communities and regions on which they rely and in which they reside (Pew Research Center 2017; Inglehart and Norris 2016).

Ireland is an example of this seismic shift (Costello and Hazelkorn 2018). From 3200 students at the beginning of the 19th century attending five universities, there are around 170,000 students today, estimated to rise to 182,000 by 2020 and 211,000 by 2028 . Over the last sixty years, participation rates have risen from about $10 \%$ at the beginning of the 1960 s to $20 \%$ by 1980 and about $60 \%$ today, which places Ireland at the upper end of EU and OECD benchmarking levels (Clancy 2015, 36; HEA 2015). Fundamental to this expansion has been sustained policy emphasis on widening access at increasingly advanced levels, from the introduction of free secondary education in the mid-1960s to free undergraduate education in 1996. Today, there are seven universities and fourteen Institutes of Technology (IoT), alongside a small number of other publicly-aided institutions, and a growing number of for-profit private institutions (HEA 2016).

Initially, institutional funding was determined by a combined input and legacy model; over the last decade or so, three broad approaches have been adopted for monitoring and steering. 
1 Performance via greater transparency, using greater levels of reporting on what is being delivered by higher education, such as regarding graduate outcomes, student feedback, quality reviews, etc.;

2 Performance via funding, using particular targets to widen access or reduce drop out, etc.; and

3 Performance assessment via compacts, using a set of guidelines and a process of negotiated agreements or compacts.

Often overlapping, there has nonetheless been an evolution from remote or hands-off governance towards more direct steerage in response to the changed economic and political climate. The idea for formalizing the "social contract" between Ireland's HEIs and society was recommended in the National Strategy for Higher Education to 2030. It referred to the desire to establish a

new contractual relationship or service level agreement...to ensure that the requirements for performance, autonomy and accountability are aligned (DES 2011, 14).

While there has been a strong social justice and equity component to Irish education policymaking since the foundation of the state in 1922 (Hazelkorn et al. 2015), formally embedding national objectives as a strategic purpose into higher education policy marked a radical departure.

IoT institutions had been established between 1967 and 2000 with the mission to underpin economic development (GoI 1967; Walsh 2009). In contrast, the universities had a broader remit; however, since 1997, they have had a legislative requirement "to support and contribute to the realisation of the national and social development" (Universities Act 1997). Recent developments have strengthened this component. The government has formally articulated societal requirements in the form of a performance framework (DES 2013). In turn, HEIs are asked, through a series of institutional submissions, discussions and negotiations, called strategic dialogue, to affirm how, according to their mission, they will meet these national objectives. The forthcoming revised resource allocation model is likely to endorse these linkages more directly.

A big factor behind these developments has been the depth of the global financial crisis and the resulting Irish banking collapse which elevated concerns around cost, effectiveness, efficiency and impact to a national obsession as taxpayers experienced tax hikes and cuts to salary and services. ${ }^{2}$ This has fed broader public, political and media discordance with what is perceived as the unwillingness of various organisations and elites, including the police, banks, charities and politicians in receipt of public funds or benefit, to be fully transparent with respect to the use of these funds and/or benefits (see Quinn 2016). The failure by one university to respond to what were seen as legitimate allegations of financial

\footnotetext{
${ }^{2}$ Funding levels for higher education collapsed at the same time that student demand increased, resulting in a significant decline in funding per student, dropping from about $€ 12,000$ per student in 2008 to a little over $€ 9000$ by 2015 , and unemployment rose from about $4 \%$ in 2008 to over $12 \%$ by 2012 .
} 
irregularities by whistle-blowers, which included preferential payments to senior staff, provoked a firestorm of critical commentary. Newspaper reports and a television programme raised a number of questions about public accountability, and there were animated discussions at the parliamentary Public Accounts Committee, especially when it was revealed that presidents of several HEIs had been less than forthcoming in their answers or material provided (RTÉ 2017a, b). These events have led to the entire sector coming under increased public scrutiny, with allegations of arrogance. A formal teaching evaluation, modelled perhaps on the UK Teaching Excellence Framework (McGrath 2017), has been mooted as well as legislative changes strengthening the regulatory authority of the Higher Education Authority (O'Brien 2017).

The extent to which these incidents have raised questions about the sector's "political" judgement and "own goal" is certainly warranted. However, more significantly, these developments signal profound changes around public trust in colleges/universities and elites, and shifting boundaries around the public interest in higher education. Twenty years ago, when the Universities Act 1997 was introduced, the universities received considerable public and political support strengthening university autonomy; indeed, this Act is the only legislation regulating the relationship between universities and the public interest. It is notable how strongly felt then was the respect for the autonomy of the universities to manage their internal affairs, and a clear concern to ensure that governments did not control the universities. Such was the outcry from Opposition parties and the media against a perceived take-over of the universities by the State, that the original Bill had well over 100 amendments during its enactment. Crucially, the then government felt it necessary to write into the Act strong protections for institutional autonomy and academic freedom giving to government, through the agency of the Higher Education Authority, limited capacity to interfere in the internal affairs of a university (Boland \& Hazelkorn 2017). No such lobby exists today. Hence, whether students and the "public" genuinely distrust higher education or policymakers, the media or others are encouraging such distrust, no longer matters; a problem exists and it is affecting higher education.

\section{Emerging Issues in the Global Era}

Defining and maintaining quality, guided by norms of peer review, has been a cornerstone of the academy since the 17th century, underpinning academicprofessional self-regulation and self-governance (Rowland 2002, 248). University autonomy has been an important symbol of independence of thought and decision-making, enabling the academy to shape its curriculum and research, be the primary determinant of quality, and speak "truth to power", even in politically challenging environments. University autonomy was re-affirmed in the Bologna 
Declaration with reference to the Magna Charta Universitatum (1988), ${ }^{3}$ and it continues to be recognised as a core principle in most national legislation as well as by the European Commission.

These values were further strengthened by the Bologna Process and enshrined in quality assurance processes which are built around institutional ownership of quality with assessment mechanisms which aim to enhance rather than enforce or measure quality. Since 2005, key components of institutional based and oriented quality assurance have been reinforced by the adoption of qualifications frameworks at the European and national levels, recognition and the promotion of learning outcomes, and the paradigm shift towards student-centred learning and teaching (DG Education 2017). These actions have been underpinned by the European Association for Quality Assurance in Higher Education (ENQA) and the European Quality Assurance Register for Higher Education (EQAR) and formalised in the European Standards and Guidelines for Quality Assurance across the European Higher Education Area. Over the years, a meta-structure (Maassen and Stensaker 2011) has emerged, "reinforced by the international tide of "new governance" that enthused national governments... [and which] stressed transparency, accountability, and value-for-money for taxpayer-funded expenditure" far beyond the European Union (King 2018).

Ensuring qualifications are of high quality and internationally comparable and transferable is a precondition for participation in the global economy and for talent mobility. With the surge in the number and range of educational programmes and providers, inter alia for-profit and transnational/cross-border higher education, there are corresponding concerns about standards, ethics, and consumer protection. While quality and pursuit of excellence are institutional strategic goals, they are also national and global goals - albeit with slightly different implications (Eaton 2016). In this environment, there has been a growing dissatisfaction with the usefulness, robustness and comparability of traditional collegial mechanisms. Several issues come to the fore. ${ }^{4}$

First, quality is a complex term, and "despite the fact that the concept is used widely, there is no agreed-upon definition... or how it should be measured, much less improved. Everyone has their own perspective, as evidenced by the different approaches, methodologies, and choice of indicators" (Hazelkorn et al. 2018; Valeikienè 2017). Emphasis has primarily been on teaching and learning, and research, but increasingly quality extends beyond internal matters and reflects the capacity and capability of higher education to meet a variety of societal needs and demands. Collectively, these different attributes matter because of the significance of (higher) education for national competitiveness and global positioning; hence,

\footnotetext{
3،"The university is an autonomous institution at the heart of societies differently organised because of geography and historical heritage; it produces, examines, appraises and hands down culture by research and teaching. To meet the needs of the world around it, its research and teaching must be morally and intellectually independent of all political authority and intellectually independent of all political authority and economic power." Magna Charta, 1988.

${ }^{4}$ This section draws on issues raised in Hazelkorn et al. 2018.
} 
there is increasingly a geo-political aspect to quality. It is often used in association or conterminously with "excellence" as if to assert or emphasize the objective of quality. This means that quality is effectively shaped by who-ever decides, by the choice of methodology (qualitative and/or quantitative) and the indicators - rather than on the basis of standards. This means quality can appear to be variable, and hence a cause of great perplexity and unhappiness. As academics, we may understand why that is so and why context matters, but to others, this seems to be just a(nother) form of obfuscation.

Second, quality assurance has been the mainstay of the academy, but the inability to provide comparability and to provide evidence in a usable and easily digestible format has become a major handicap. In the US, accreditation has come up against similar challenges. Without doubt, promotion of and embedding a quality culture is a vital first step, especially for countries and institutions with no history or understanding of these issues (Sursock 2003). Academic self-reporting and self-governance require taking meaningful ownership of quality management by placing responsibility on higher education. But the emergence of a coterie of internationally mobile peer-reviewers - a quality "industry" - carries many of the same limitations inherent in peer-review for research. Moreso, despite its observable virtues, quality assurance is often seen as being/becoming too process-oriented and insufficiently focused on real outcomes. Indeed, it often seems that the process of assessing and monitoring is just that - a process, which is arguably an inefficient use of public resources and people's time, a system which benefits the academy (which has a proclivity towards process-oriented actions) more than students or society and is not scalable in any meaningful way.

Third, while quality-standards remain important, higher education is now being asked additional questions about performance and productivity which get to the heart of the matter. Performance involves questions of how well the institutions operate vis-à-vis their goals and those of society; hence, the focus is on actual outcomes and outputs rather than simply the process. While quality assurance focused traditionally on individual institutions, performance-related deliberations have shifted attention onto academic and professional staff and students. There has been a long history of measuring research activity, but questions are now being asked about what academics produce through their teaching, and issues of academic outputs and outcomes, such as progression and graduate employment. This may be a welcome rejoinder to global rankings which overwhelmingly focus on research, but it speaks directly to public and political perceptions about what academics do all day or all year. Thus, what people want to know is how effectively students are learning, what they are achieving, and how personnel, institutions and the systems overall help students to succeed.

Fourth, assessing and evaluating performance is both a controversial and complex process. Traditional approaches have relied on collegiality, expert judgment, and peer review. More quantitative and externally-driven approaches have emerged in recent decades, including, inter alia, international as well as national rankings and bibliometric systems; multi-dimensional profiling and classification tools; teaching excellence assessments, learning gain initiatives, and wider usage of learning 
analytics; government databases and "scorecards" alongside open-source websites; institution- and even department- or field-based approaches; and national and international benchmarking frameworks such as that proposed by the OECD (Hazelkorn and Gibson 2018). At a national level, various countries are experimenting with re-constructing the "social contract" using a set of negotiations, such as performance agreements or compacts. While the latter enables both government and institutions to set goals (apropos the Irish case aforementioned), this approach can't respond to wider demands for international comparability. Students have been an important part of the process. But, as our systems become even more diverse, and society looks for evidence of value and impact, the participation of third-parties, including business and employers and civil society, becomes inevitable. Indeed, new technologies will make the participation of citizens easier than ever with the potential to by-pass the academy entirely.

Finally, each approach has shortcomings and is controversial in some way, but they all reflect growing frustration with the inability to identify an acceptable and transparent approach for assessing, measuring, comparing and thus improving higher education outcomes for students and society. The significance of these different instruments for underpinning and governing international higher education is illustrated by the fact that actions-involving myriad players: higher education institutions and organisations, academics and governments as well as a web of knowledge intelligence businesses - are now being progressed, with great urgency, at national as well as at international and supra-national levels. No doubt, the challenges associated with this rapidly expanding and diverse "brave new world" are problematic but it could be argued that the academy's grip on "quality" has been overtaken by events. There is, therefore, an imperative on universities and colleges, of all missions and around the world to "start driving the bus" if they are not to be left on the side of the road.

\section{Chapters in This Section}

There are eight papers in this section which look at different aspects of the accountability and transparency debate. Jongbloed, Vossensteyn, van Vught and Westerheijden set the scene by looking at the development of transparency instruments and evaluating their impact on higher education governance and policy over the past 10 years or so. In particular, the paper focuses on changes in governance and what that has meant in terms of public and governmental "intervention", with particular reference to redefining the social contract.

This is followed by four papers which provide interesting case studies from different parts of the world, scrutinizing real-life experiences and what can be learned. Weingarten and Hicks examine how Ontario, Canada is developing new ways to measure higher education performance and student outcomes by linking the system directly to government objectives. Morris charts significant growth in the number and variety of transparency tools in Wales and England over the last fifty 
years, pointing to the fact that each policy development has added sedimentary layers of control. Gunn looks specifically at the new UK Teaching Excellence Framework (TEF) and asks to what extent TEF can actually meet policy objectives. Finally, Huang offers a view from Asia and in particular looking at the experience of China and Japan; are there lessons here for Europe?

Finally, three papers look at possible future issues and directions for the transparency and accountability agenda. Murphy and Dębowski focus on non-formal qualifications. One of the defining characteristics of advanced economies is higher participation levels which has helped transform the student cohort and multiplied the number of diverse. Non-formal qualifications, which have existed outside the traditional academic community, are becoming both more common and attractive but there are implications for qualifications frameworks. Szabo and Tück analyse the path undertaken by and commitment of Bologna signatory countries to external quality assurance procedures and assess the extent to which they have succeeded in realising trust and transparency. Finally, Lennon looks at the effectiveness of learning outcomes as a means to make quality more transparent. The paper challenges conventional assumptions and suggests learning outcomes policies are often misaligned with goals, misapplied in implementation, and misdirected in goal choice; however, rather than dismissing the concept, more work is required.

\section{References}

Boland, T., \& Hazelkorn, E. (2017, December 12). Public interest and higher education. The Irish Times. Retrieved from https://www.irishtimes.com/news/education/time-to-rebuild-trustbetween-higher-education-and-political-system-1.3316603on.

Bovens, M. (2003). Public accountability. Paper for the EGPA annual conference, Oeiras Portugal September 3-6, 2003 to be presented in workshop 8 (Ethics and integrity of governance) (Vol. 8). http://doi.org/10.1093/oxfordhb/9780199226443.003.0009.

Bovens, M., Goodin, R. E., Schillemans, T., Bovens, M., Schillemans, T., \& Goodin, R. E. (2014). Public accountability. In M. Bovens, R. E. Goodin, \& T. Schillemans (Eds.), The oxford handbook of public accountability (pp. 1-20). Oxford: Oxford University Press. http://doi.org/ 10.1093/oxfordhb/9780199641253.013.0012.

Calderon, A. (2012, September 2). Massification continues to transform higher education. Retrieved September 2, from University World News, Issue 237 www.universityworldnews. com/article.php?story $=20120831155341147$.

Carnevale, A. P., Smith, N., \& Strohl, J. (2013). Recovery-Job Growth and Education Requirements through 2020. Washington DC: Centre on Education and the Workforce, Georgetown University. Retrieved from https://cew-7632.kxcdn.com/wp-content/uploads/ 2014/11/Recovery2020.FR_.Web_.pdf.

Castells, M. (1996). The rise of the network society: The information age: Economy, society, and culture. Oxford: Blackwell.

Clancy, P. (2015). Irish higher education: A comparative perspective. Dublin: Institute of Public Administration.

Costello, F., \& Hazelkorn, E. (2018, forthcoming). Assessing teaching and learning in Ireland. In H. P. Weingarten (Ed.), Assessing the quality of a postsecondary education: International perspectives. Toronto: Higher Education Quality Council of Ontario.

Dahler-Larsen, P. (2011). The evaluation society. Stanford: Stanford University Press. 
DES. (2011). National strategy for higher education to 2030. Department of Education and Skills: Report of the Strategy Group. Dublin.

DES. (2013). Higher education system performance framework, 2014-2016. Dublin: Department of Education and Skills. Retrieved from http://hea.ie/assets/uploads/2017/06/DES-SystemPerformance-Framework.pdf.

DG Education. (2017). Quality and relevance in higher education. Brussels: European Commission. Retrieved from https://ec.europa.eu/education/policy/higher-education/qualityrelevance_en.

Dill, D. D., \& Beerkens, M. (2010). Public policy for academic quality. Analyses of innovative policy instruments. Dordrecht: Springer.

Eaton, J. (2016). The question for quality and the role, impact and influence of supra-national organisations. In E. Hazelkorn (Ed.), Global rankings and the geopolitics of higher education. Understanding the influence and impact of rankings on higher education, policy and society (pp. 324-338). London and New York: Routledge.

Enders, J. (2004). Higher education, internationalisation and the nation-state: Recent developments and challenges to governance theory. Higher Education, 47(3), 361-382. https://doi.org/10. 1023/B:HIGH.0000016461.98676.30.

Erkkilä, T. (2007). Governance and accountability—a shift in conceptualisation Public Administration Quarterly (pp. 1-38).

Erkkilä, T., \& Piironen, O. (2009). The iron cage of governance indicators. In R. W. Cox (Ed.), Ethics and integrity in public administration. Concepts and cases (pp. 125-145). Armonk, New York, London, UK: M. E. Sharpe.

Estermann, T., \& Nokkala, T. (2009). University autonomy in Europe. Exploratory study. Brussels: European University Association.

Eurobarometer. (2009). Students and higher education reform. Survey among students in higher education institutions, in the EU Member States, Croatia, Iceland, Norway and Turkey. Special Target Survey. Analytical Report Brussels: DG Education and Culture. Retrieved from http:// ec.europa.eu/public_opinion/flash/fl_260_en.pdf.

Eurostat. (2017a, June). Tertiary education statistics, statistics explained. Extract from Further Eurostat Information, Main tables and Database. Retrieved November 20, 2017, from http://ec. europa.eu/eurostat/statistics-explained/index.php/Tertiary_education_statistics.

Eurostat. (2017b, June). Education attainment statistics, Statistics Explained. Extract from Further Eurostat Information, Main tables and Database. Further Eurostat Information, Main tables and Database. Retrieved from http://ec.europa.eu/eurostat/statistics-explained/index.php/ Educational_attainment_statistics.

Eurostat. (2017c). Glossary: EU 2020 Strategy. Retrieved from http://ec.europa.eu/eurostat/ statistics-explained/index.php/Glossary:EU_2020_Strategy.

Ferlie, E., Musselin, C., \& Andresani, G. (2008). The steering of higher education systems: a public management perspective. Higher Education, 56(3), 325-348. https://doi.org/10.1007/ s10734-008-9125-5.

Fisher, K. (2017, 9 February). Even before the travel ban, signs of weakening interest from students Abroad. Retrieved February 9, from http://www.chronicle.com/article/Even-Beforethe-Travel-Ban/239152.

Gallagher, M. (2010). The accountability for quality agenda in higher education from Group of 8 . Retrieved from https://go8.edu.au/publication/accountability-quality-agenda-higher-education.

Gallup. (2017). The AGB 2017 Trustee Index. Trustees and higher education's proposition, value. Washington DC: Association of Governing Boards of Universities and Colleges.

GoI (Government of Ireland). (1967). Steering committee on technical education: Report to the Minister for Education on Regional Technical Colleges. Dublin: Government of Ireland.

Hazelkorn, E. (2015). Rankings and the reshaping of higher education. The battle for world-class excellence. Basingstoke: Palgrave MacMillan.

Hazelkorn, E. (2016). Private providers: What role should they play in the Irish higher education landscape? Retrieved from Higher Education Authority http://hea.ie/assets/uploads/2017/04/ 6th_hea_forward-look_forum_-_discussion_paper.pdf. 
Hazelkorn, E. (2017). Rankings and higher education: reframing relationships within and between states Working Paper Series No. 19. London: Centre for Global Higher Education. Retrieved from http://www.researchcghe.org/perch/resources/publications/wp19.pdf.

Hazelkorn, E., Coates, H., \& McCormick, A. C. (2018 forthcoming). Quality, performance, and accountability: Emergent challenges in the global Era. In E. Hazelkorn, H. Coates, \& A. C. McCormick (Eds.), Research handbook on quality, performance and accountability in higher education. Cheltenham: Edward Elgar.

Hazelkorn, E., \& Gibson, A. (2017). Public goods and public policy: What is public good, and who and what decides? CGHE Working Papers No. 18. London: Centre for Global Higher Education. Retrieved from http://www.researchcghe.org/perch/resources/publications/wp18.pdf.

Hazelkorn, E., \& Gibson, A. (2018, forthcoming). The impact and influence of rankings on the quality, performance and accountability agenda. In E. Hazelkorn, H. Coates, \& A. C. McCormick (Eds.), Research handbook on quality, performance and accountability in higher education. Cheltenham: Edward Elgar.

Hazelkorn, E., Gibson, A., \& Harkin, S. (2015). From Massification to globalisation: Reflections on the transformation of Irish higher education. In K. Rafter \& M. O'Brien (Eds.), The state in transition. Essays in Honour of John Horgan (pp. 235-260). Dublin, Ireland: New Island Books.

HEA. (2015). National plan for equity of access to higher education 2015-2019. Dublin: Higher Education Authority.

HEA. (2016). Key facts and figures. Dublin: Higher Education Authority.

HEFCE. (2010). Public perceptions of the benefits of higher education. Bristol and London: Higher Education Funding Council for England.

ICEF Monitor (2015, 30 November). New OECD report summarises global mobility trends. Retrieved from http://monitor.icef.com/2015/11/new-oecd-report-summarises-global-mobilitytrends/.

Immerwahr, J., \& Johnson, J. (2010). Squeeze Play 2010: Continued public anxiety on cost, harsher judgments on how colleges are run. Washington D.C. and San Jose: Public Agenda and National Center for Public Policy and Higher Education.

Inglehart, R. F., \& Norris, P. (2016). Trump, brexit, and the rise of populism: Economic have-nots and cultural backlash. HKS Working Paper No. RWP16-026.

Ipsos MORI (2010). Public perceptions of the benefits of higher education. Bristol: Higher Education Funding Council for England. Retrieved from http://www.hefce.ac.uk/media/hefce/ content/pubs/2010/rd2410/rd24_10.pdf.

King, R. (2009). Governing Universities Globally. Organizations, Regulation and Rankings. Cheltenham: Edward Elgar.

King, R. (2018, forthcoming). Challenges for quality assurance in higher education: The regulatory turn. Cheltenham: Edward Elgar.

Lederman, D. (2017, December 15). Is higher educaiton really losing the public? Inside Higher $E d$. Retrieved from https://www.insidehighered.com/news/2017/12/15/public-really-losingfaith-higher-education.

Leveille, D. E. (2013). Accountability in postsecondary education revisited. CSHE Research \& Occasional Paper Series, 13(9).

Levy, D. C. (2012). How important is private higher education in Europe? A regional analysis in global context 1. European Journal of Higher Education, 47(2).

Lijphart, A. (2012). Patterns of democracy. New Haven, CT: Yale University Press.

Foundation, Lumina. (2013). America's call for higher education redesign. Study of the American Public's opinion on higher education. Indianapolis: Lumina Foundation.

Maassen, P., \& Stensaker, B. (2011). The knowledge triangle, European higher education policy logics and policy implications. Higher Education, 61(6), 757-769.

Magna Charta. (1988). Magna Charta Universitatum. Retrieved from http://www.magna-charta. org/resources/files/the-magna-charta/english.

Marriam-Webster. (2017, November 10). Accountability. https://www.merriam-webster.com/ dictionary/accountability. 
Maslen, G. (2012, February 19). Wordwide student numbers forecast to double by 2025. University World News, (209). Retrieved February 19, from http://www.universityworldnews. com/article.php?story=20120216105739999.

McGrath, D. (2017). Government to undertake review of higher education, as funding debate continues. University Times. Retrieved July 25, from http://www.universitytimes.ie/2017/07/ government-to-undertake-review-of-higher-education-amid-growing-impatience-for-a-newfunding-model/.

Middlehurst, R., \& Fielden, J. (2011). Private providers in UK higher education: Some policy options. Oxford: Higher Education Policy Institute (HEPI). Retrieved from http://www.hepi.ac. uk/2011/05/05/private-providers-in-uk-higher-education-some-policy-options/.

Mohamedbhai, G. (2017, November 3). The changing landscape of private higher education. University World News, (481). Retrieved November 3, from http://www.universityworldnews. com/article.php?story=2017103110332862.

Mok, K. H., Han, X., Jiang, J., \& Zhang, X. (2017, June). International and transnational learning in higher education: a study of students' career development in China CGHE Working Paper no. 21. London: Centre for Global Higher Education.

Morrell, K. (2009). Governance and the public good. Public Administration, 87(3), 538-556.

Neave, G. (1998). The evaluative state reconsidered. European Journal of Education, 33(3), 265-284.

Neave, G. (2012). The evaluative state, institutional autonomy and re-engineering higher education in Western Europe: The prince and his pleasure. Basingstoke: Palgrave Macmillan.

O'Brien, C. (2017, November 6). New powers to investigate universities spark fears over autonomy. Retrieved November 6, from https://www.irishtimes.com/news/education/newpowers-to-investigate-universities-spark-fears-over-autonomy-1.3281016.

OECD. (2014). Who studies abroad and where education at a glance 2014: OECD indicators. Paris: Organization for Economic Co-operation and Development. Retrieved from http://www. oecd.org/edu/EAG2014-Indicator\%20C4\%20(eng).pdf.

OECD. (2017). Education at a glance. Paris: Organization of Economic Co-operation and Development.

Pew Research Center. (2017). Sharp partisan divisions in views of national institutions. Washington DC: Pew Research Center.

Public Agenda. (2016). Public opinion on higher education. Retrieved September 12, from https:// www.publicagenda.org/pages/public-opinion-higher-education-2016.

Quinn, P. (2016, May 18). Opinion: Shining a light on Ireland's charities. Retrieved May 18, from https://www.irishtimes.com/opinion/opinion-shining-a-light-on-ireland-s-charities-1.2651046.

Robertson, S. L., Dale, R., Olds, K., \& Dang, Q. A. (2016). Introduction: Global regionalisms and higher education. In S. L. Robertson, R. Dale, K. Olds, \& Q. A. Dang (Eds.), Global regionalisms and higher education. Projects, processes, politics. (pp. 1-23). Cheltenham: Edward Elgar.

Rowland, F. (2002). The peer-review process. Learned publishing. Learned Publishing, 15, $247-258$.

RTÉ Documentary. (2017a). Universities unchallenged. (May 26). Retrieved from https://www. rte.ie/news/primetime/2017/0526/878118-rte-investigates-universities-unchallenged/on.

RTÉ News. (2017b). Ice sculpture part of € $13 \mathrm{k}$ retirement party for ex- CIT president. Retrieved November 16, from RTÉ News https://www.rte.ie/news/politics/2017/1116/920599retirement-party/.

Salmi, J. (2015). Is big brother watching you? The evolving role of the state in regulating and conducting quality assurance. (Vol. 2): CHEA/CIQG Publication Series.

Scott, P. (1998). Massification, internationalization and globalization. In P. Scott (Ed.), The globalization of higher education (pp. 108-129). Buckingham: Open University Press.

Sursock, A. (2003). Developing an internal quality culture in European Universities. Report on the Quality Culture Project, 2002-2003. Brussels: European University Association. on

Sursock, A. (2015). Trends 2015: Learning and teaching in european universities. Brussels: European Universities Association. Retrieved from http://www.eua.be/Libraries/publicationshomepage-list/EUA_Trends_2015_web. 
Teichler, U., \& Bürger, S. (2005). The changing numbers and composition of student enrolment in Europe and Japan. Draft. Paris: Organization of Economic Co-operation and Development. Retrieved from http://www.oecd.org/innovation/research/37552327.pdf.

Trow, M. (1974/2010). Problems of the transition from elite to mass higher education. In M. Burrage (Ed.), Martin Trow: Twentieth-century higher education-From Elite to mass to universal. Baltimore, MA: Johns Hopkins University Press.

UNESCO. (2017, April). Six ways to ensure higher education leaves no one behind. Policy Paper 30. Retrieved April from http://unesdoc.unesco.org/images/0024/002478/247862E.pdf.

Universities Act. (1997). Dublin: Irish statute book. Retrieved from http://www.irishstatutebook. ie/eli/1997/act/24/section/12/enacted/en/html\#sec12.

Valeikiene, A. (2017, November 17). The politics of quality assurance in higher education. Retrieved November 17, from University World News http://www.universityworldnews.com/ article.php?story $=2017111610182154$.

Vincent-Lancrin, S. (2008a). The reversal of gender inequalities in higher education: An on-going trend. In Higher education to 2030, Vol. 1: Demography. Retrieved from https://www.oecd. org/edu/ceri/41939699.pdf.

Vincent-Lancrin, S. (2008b). What is the impact of demography on higher education systems? A forward-looking approach for OECD countries. In Higher education to 2030, Vol. 1: Demography (pp. 41-103). Paris: Organization of Economic Co-operation and Development. Retrieved from https://www.oecd.org/edu/ceri/41939423.pdf.

Walsh, J. (2009). The politics of expansion: The transformation of educational policy in the republic of Ireland, 1957-72. Manchester: Manchester University Press.

Webometrics. (2017, January). Ranking Web of Universities. Retrieved July http://www. webometrics.info/en/node/54.

WHED. (2017). World higher education database. Paris: International Association of Universities. Retrieved from http://whed.net/home.php.

WIPO. (n.d.). What is WIPO. Geneva: World Intellectual Property Organization. Retrieved from http://www.wipo.int/about-wipo/en/.

World Bank. (2016). Gross enrolment ratio, tertiary, both sexes (\%), 1970-2016. Retrieved from https://data.worldbank.org/indicator/SE.TER.ENRR.

WTO. (n.d.). What is the TWO? Geneva: World Trade Organization. Retrieved from https://www. wto.org/english/thewto_e/whatis_e/whatis_e.htm.

Zumeta, W. M. (2011). What Does It mean to be accountable? Dimensions and implications of higher education's public accountability. The Review of Higher Education, 35(1), 131-148. https://doi.org/10.1353/rhe.2011.0037.

Open Access This chapter is licensed under the terms of the Creative Commons Attribution 4.0 International License (http://creativecommons.org/licenses/by/4.0/), which permits use, sharing, adaptation, distribution and reproduction in any medium or format, as long as you give appropriate credit to the original author(s) and the source, provide a link to the Creative Commons license and indicate if changes were made.

The images or other third party material in this chapter are included in the chapter's Creative Commons license, unless indicated otherwise in a credit line to the material. If material is not included in the chapter's Creative Commons license and your intended use is not permitted by statutory regulation or exceeds the permitted use, you will need to obtain permission directly from the copyright holder.

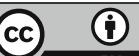

